\title{
PEMAKNAAN ISTRI NARAPIDANA TEROR TERHADAP TINDAKAN SUAMI
}

\author{
Any Rufaidah, a, \\ Sarlito W. Sarwono ${ }^{b, c}$, \\ Idhamsyah Eka Putra ${ }^{b, c}$ \\ ${ }^{a}$ Sekolah Tinggi Agama Islam Nahdlatul Ulama (STAINU), \\ Jl. Taman Amir Hamzah No. 5, Pegangsaan, Menteng \\ Jakarta Pusat 10320, Indonesia \\ ${ }^{b}$ Universitas Persada Indonesia YAI \\ Jl. Diponegoro No. 74 \\ Jakarta Pusat 10430, Indonesia \\ ${ }^{c}$ Pusat Riset Ilmu Kepolisian (PRIK) Universitas Indonesia \\ Gedung Program Pascasarjana \\ Kampus Universitas Indonesia \\ J1. Salemba Raya No. 4, Jakarta 10430, Indonesia \\ le-mail: anyrufaidah@gmail.com
}

\begin{abstract}
Terrorism is one of the topics that have been studied much by psychology at least in one and half last decades. Many research explained motivation, personality tendention, and thinking structure of terrorist's. But studies to terrorist's wives were not much conducted yet. Terrorist's wives are individuals which not always have same thought with the husband. Eventhough they have high conformity level, not all of them adopt husband's thought. There are wives that more inclusive or more radical than their husband. This research purpose to know how wives means terror act of husband. Whether they accept or decline. Wive's interpretation is also explain whether they agree or deny to terror act commontly. The participants of this research are 4 wives of terror convict in Jakarta, Semarang, and Cilacap. The approach used is qualitative with interview method and qualitative thematic analysis as analysis technic. The data is displayed descriptively with excerpts of interview to give strengthening. The result shows that 2 wives think that their husbands 'terror act is right. They handling husbands' acts are da'wah and struggling for Islam, not terror. 2 others wives think that their husbands are wrong. Their husbands are convicted due to against the law. If husband does not against the law, they will not be
\end{abstract}

Tulisan ini merupakan bagian dari penelitian "In-Prison Re-Education Programme: A Strategy in Countering ISIS Ideology for TerrorConvicts and Families" (2016) yang diketuai Profesor Sarlito W. Sarwono di bawah Pusat Riset Ilmu Kepolisian (PRIK), Program Pascasarjana Universitas Indonesia. 
convicted. This research also finds that the difficult live which wive facing for convict time of husband is not always linear with declining to terror act.

Key words: terrorism; interpretation; terror convict's wife.

\begin{abstract}
Abstrak - Terorisme menjadi salah satu topik yang banyak dikaji oleh ilmu psikologi setidaknya satu setengah dasawarsa terakhir. Berbagai penelitian telah menjelaskan motivasi, kecenderungan kepribadian, dan struktur berpikir para teroris. Namun penelitian terhadap istri teroris belum banyak dilakukan. Istri teroris adalah individu yang tidak selalu memiliki pemikiran sama dengan suami. Meskipun memiliki kepatuhan yang tinggi, tidak semuanya mengadopsi faham suami. Ada istri yang lebih inklusif, ada pula yang lebih radikal dari suami. Penelitian ini bertujuan untuk mengetahui bagaimana istri memaknai tindakan teror suami. Apakah mereka membenarkan atau menyalahkan. Pemaknaan istri sekaligus dapat mendeskripsikan apakah mereka setuju atau menolak tindakan teror. Partisipan penelitian adalah 4 istri narapidana teror (napiter) di Jakarta, Semarang, dan Cilacap. Pendekatan yang digunakan adalah kualitatif dengan metode wawancara dan qualitative thematic analysis sebagai teknik analisis. Data disajikan secara deskriptif disertai kutipan-kutipan hasil wawancara untuk memberikan penguatan. Hasil penelitian menunjukkan 2 istri memandang tindakan terorisme suaminya benar. Mereka memaknai tindakan suami adalah dakwah dan perjuangan Islam, bukan teror. Dua istri lainnya memandang suaminya yang salah. Suami ditangkap karena melanggar hukum. Jika tidak melanggar hukum suami mereka tidak akan di penjara. Penelitian juga menemukan bahwa kesulitan yang dialami istri selama masa tahanan suami tidak selalu linier terhadap penolakan terhadap tindakan teror.
\end{abstract}

Kata kunci: terorisme; pemaknaan; istri narapidana teror.

\title{
PENDAHULUAN
}

Terorisme merupakan topik yang mendapat cukup banyak perhatian dari ilmu psikologi. Jika ditelusuri dari literatur-literatur ilmiah, studi psikologi dan terorisme tidak sulit ditemukan (misal: Kruglanski \& Fishman, 2006; Moghaddam, 2005; Post, 2005). Di Indonesia tercatat nama Sarlito W. Sarwono, Mirra Noor Milla, Idhamsyah Eka Putra, yang telah melakukan berbagai kajian psikologi dan terorisme.

Sarwono (2012) menemukan cara-cara mantan narapidana dan narapidana terorisme tergabung dalam kelompok terorisme, yaitu ikut-ikutan teman, ingin belajar Islam, pengaruh pendidikan Islam radikal di pesantren, terikat oleh baiat, dimanfaatkan teman untuk membantu aksi teror, dan dijanjikan pekerjaan.

Milla dan Faturochman (2009) pernah melakukan penelitian tentang proses pembentukan identitas mujahid global pada narapidana di Indonesia. Hasil penelitian itu menemukan dua proses pembentukan 
identitas mujahid. Pertama, subordinasi identitas pribadi ke dalam identitas kelompok agama. Kedua, ideologisasi jihad di dalam kelompok.

Sementara itu, penelitian Putra dan Sukabdi (2013) menemukan tiga alasan narapidana terorisme di Indonesia, yaitu: karena Indonesia negara sedang berperang, meyakini bom bunuh diri adalah tindakan mulia, karena Barat menjajah negara-negara Muslim dan pemerintah Indonesia adalah sekutu Barat yang korup.

Studi banyak dilakukan seiring dengan merebaknya kelompok-kelompok radikal dan aktivitas terorisme yang permulaannya ditandai oleh pengeboman World Trade Centre (WTC) pada tahun 2001. Di Indonesia sendiri terorisme mulai ramai dibicarakan sejak bom Bali 1 dan 2, Bom JW Marriot, dan Bom Ritz Carlton (Nursalim, 2014). Sebelum itu, studi terorisme dilakukan misalnya oleh oleh Bandura (1990) dalam Mechanisms of moral disengagement dan Ross (1996) dalam A model of the psychological causes of oppositional political terrorism.

Pertanyaan mendasar psikologi terkait terorisme adalah: "Apakah teroris adalah orang-orang yang mengalami gangguan kejiwaan atau gangguan kepribadian?” McCauley (2002) menyatakan 30 tahun lalu (dari tahun 2002) pertanyaan itu telah dibahas secara serius. Riset-riset psikologis tidak menemukan adanya psikopatologi ataupun gangguan kepribadian pada teroris. Hasil wawancara kepada teroris dan mantan teroris hanya menemukan sedikit gangguan setelah hasil penilaian mereka dicocokkan dengan DSM American Psychiatric Association.

Untuk meyakinkan temuan itu, McCauley (2002) menyarankan kita untuk membayangkan diri sebagai teroris. Kita hidup bergerilya, menjaga rahasia, dan sangat tergantung satu sama lain. Dalam kondisi seperti itu, kita tidak akan ingin jika salah satu anggota kelompok ada yang menderita gangguan jiwa. Selain itu, teroris juga dapat mengorganisir serangan dengan sukses. Tidak mungkin orang dengan gangguan jiwa dapat merencanakan dan mengatur serangan sampai sukses. Namun McCauley menyisakan pertanyaan mengenai teroris yang ingin melakukan bom bunuh diri. Orang seperti itu mungkin memang mengalami kecenderungan psikopatologi.

Psikologi juga melakukan penelitian terhadap motivasi tindakan teror, profil pelaku, intervensi kognitif kepada narapidana dan mantan narapidana teror, dan pembekalan untuk kembali hidup di tengahtengah masyarakat. Namun demikian, studi terhadap istri teroris (napiter) masih jarang dilakukan.

Jika dilihat dari perannya, istri adalah pihak sangat penting bagi napi teror. Studi Sarwono (2016) menemukan bahwa istri berperan dalam memberikan dukungan finansial, dukungan moral, pemenuhan kebutuhan seksual, pengasuhan dan pendidikan anak, dan memutus hubungan suami dengan jaringan 
kelompok radikal. Peran yang disebutkan terakhir adalah peran positif istri dalam pencegahan aksi terorisme. Istri dapat "mengancam" suami agar tidak kembali ke jaringan kelompok radikal. Kesulitan yang dihadapi selama suami ditahan membuat mereka tidak ingin suami kembali bergaul dengan jaringan radikal. Sikap itu juga diberlakukan kepada anak-anak. Dengan peran ini, istri tidak hanya memiliki pengaruh kepada suami, namun juga kepada anak-anak yang dididiknya. Berdasarkan pentingnya posisi istri dalam mempengaruhi suami dan anak-anak, maka studi-studi terhadap mereka penting dilakukan.

Penelitian ini bertujuan melihat bagaimana pandangan istri terhadap tindakan teror suami. Apakah pemahaman istri selalu sama dengan suami mengingat di dalam kelompok radikal ketaatan seorang istri terhadap suami sangat ditekankan. Faktor-faktor yang menyebabkan pandangan istri juga dianalisis untuk memberikan penjelasan yang lebih komprehensif.

\section{Definisi Terorisme}

Hoffman (dalam Kruglanski \& Fishman, 2006) mengartikan "Terrorism (is) the deliberate creation and exploitation of fear through violence or the threat of violence in the pursuit of political change". [Terorisme adalah kreasi yang disengaja dan eksploitasi ketakutan melalui kekerasan atau ancaman kekerasan dalam perwujudan perubahan politik] (hlm. 201).

Moghaddam (2005) mengatakan "Terrorism is defined as politically motivated violence, perpetrated by individuals, groups, or state-sponsored agents, intended to instill feelings of terror and helplessness in a population in order to influence decision making and to change behavior." [Terorisme didefinisikan sebagai kekerasan bermotif politik, dilakukan oleh individu, kelompok, atau agen yang disponsori negara, dimaksudkan untuk menanamkan perasaan terteror dan tidak berdaya dalam suatu populasi untuk mempengaruhi pengambilan keputusan dan mengubah perilaku] (hlm. 161).

Terorisme juga diartikan sebagai "the use of force of violence by individuals or groups that is directed toward civilian populations and intended to instill fear as a means of coercing individuals or groups to change their political or social position" [penggunaan kekuatan kekerasan oleh individu atau kelompok yang diarahkan kepada penduduk sipil dan dimaksudkan untuk menanamkan ketakutan dengan arti memaksa individu atau kelompok untuk mengubah sikap politik dan sosial mereka] (Marsella, dalam Kruglanski \& Fishman, 2006, hlm. 201).

Selain dua definisi di atas, masih banyak definisi tentang terorisme. Schmid (dalam Victoroff, 2012) menemukan 109 definisi akademik terorisme. Hal itu disebabkan oleh banyaknya dimensi yang terdapat pada terorisme, di antaranya jenis terorisme (misal: terorisme berbasis militer dan berbasis agama), varian perilaku teror, motivasi yang melatarbelakangi, dan sasaran teror. 
Schultz (dalam Victoroff, 2012) membuat 12 dimensi yang terdapat pada terorisme, sebagai berikut: (1) Jumlah pelaku: perorangan vs kelompok; (2) Sponsor: negara vs. bagian negara vs individu; (3) Relasi ke pemerintah: anti negara/anti perusahaan/separatis vs. pro negara/pro perusahaan; (4) Lokasi: dalam negeri vs antarnegara; (5) Status militer: Sipil vs para militer atau militer; (6) Motivasi spiritual: sekuler vs religius; (7) Motivasi finansial: Idealistik vs wirausaha/pengusaha; (8) Ideologi politik: kiri/sosialis vs kanan/fasis vs. anarkis; (9) Peran hierarkis: penyandang dana vs pemimpin vs manajemen menengah vs pengikut; (10) Keinginan mati: bunuh diri vs tidak bunuh diri; (11) Sasaran: properti (termasuk data) vs individu vs massa; (12) Metode: pengeboman, pembantaian, penculikan/ penyanderaan, peracunan massal, pemerkosaan, dan lain-lain (misal: bioterorisme, terorisme dunia maya).

Dalam konteks saat ini perbedaan-perbedaan terorisme dapat ditemukan pada kelompok ISIS dan non ISIS. Kelompok ISIS membenarkan tindakan bom bunuh diri, membunuh, memperkosa, dan menganiaya orang-orang yang tidak sefaham meskipun sesama Muslim. Sedangkan kelompok non ISIS tidak membenarkan tindakan membunuh sesama Muslim. Dua kelompok itu setidaknya berbeda dalam hal keinginan mati dan metodologi.

Merari (2007) menyebut terorisme dapat memiliki makna berbeda pada setiap orang. Tidak ada kesepakatan dalam definisi terorisme. Lizardo (2008) juga menyatakan bahwa membuat kesepakatan untuk konsep terorisme adalah tugas yang sulit. Oleh karena itu di dalam literatur-literatur akademik sering dijumpai penggunaan istilah khusus, seperti political terrorism dan suicide terrorism (misal Post, 2005; Merari, 2007).

Namun demikian terdapat dua elemen yang biasanya ditemukan dalam definisi-definisi terorisme yang dapat menjadi acuan dalam memahami konsep terorisme, yaitu: (1) Terorisme melibatkan kekerasan terhadap non kombatan; (2) Aksi teroris sendiri tidak diharapkan untuk tujuan politik tetapi justru untuk mempengaruhi sasaran dan mengubah tindakan sasaran sehingga menuruti keinginankeinginan teroris (Badey; Laqueur, dalam Victoroff, 2012).

McCauley (2002) mengkategorikan terorisme ke dalam tindakan agresi instrumental, yaitu agresi yang memperhitungkan efek jangka panjang. Efek yang ingin ditimbulkan adalah rasa takut sampai kematian. Tujuan itu berbeda dengan agresi emosional yang sifatnya hanya sementara dan hanya merupakan pembalasan pada orang yang telah menyakiti, misalnya memukul orang yang telah memukul. Agresi ini diasosiasikan dengan marah. Namun demikian, McCauley juga menyebutkan aksi teror boleh jadi melibatkan agresi emosional. Karena marah maka orang melakukan teror. 
Ditinjau dari dampak yang ingin ditimbulkan, McCauley (2002) menyebutkan terorisme ingin menimbulkan kebangkrutan jangka panjang pada sasaran dan mendapatkan manfaat jangka panjang untuk diri atau kelompok teroris. Karena aksi teror negara-negara musuh mengeluarkan uang dalam jumlah besar untuk sektor keamanan. Dengan begitu mereka akan mengalami kebangkrutan finansial.

\section{Istri dan Terorisme}

Istri, bagian atau korban terorisme? Pertanyaan itu sering terdengar pada bahasan-bahasan mengenai istri terorisme. Hasil penelitian Sarwono (2016) menunjukkan istri bukanlah bagian dari terorisme. Istri tidak pernah mendapat informasi mengenai aktivitas terorisme suami di dalam kelompok ekstrimis. Studi itu menemukan hanya 1 dari 11 partisipan (istri) yang mengetahui keterlibatan suami dengan kelompok ekstrimis. Lainnya baru tahu pada saat suami ditangkap.

Suami sangat merahasiakan aktivitasnya kepada siapa pun, termasuk kepada istri. Rata-rata mereka beralasan dagang. Konsep ketaatan sering menjadi tameng untuk menghindari pertanyaanpertanyaan istri. Apabila suami tidak berkenan memberitahu, istri tidak diperkenankan memaksa. Tugas mereka hanya mengurus keluarga dan anak, tidak boleh lebih dari itu.

Para istri sangat kaget saat suaminya ditangkap. Bahkan di antara mereka ada yang masih sering histeris meskipun penangkapan sudah terjadi bertahun-tahun lalu. Beban psikologis karena kehilangan pasangan, stigma dari masyarakat, beban membesarkan anak tanpa suami, dan beban ekonomi memberi tekanan psikologis berat kepada para istri. Di antara partisipan studi Sarwono (2016) memilih tidak pulang kampung selama 3 tahun untuk menghindari omongan-omongan tidak menyenangkan dari tetangga.

Berdasarkan temuan di atas, posisi istri dalam lingkaran terorisme adalah korban. Pertama, istri tidak mengetahui aktivitas suami di dalam kelompok ekstrimis. Kedua, istri menerima dampak psikologis karena kehilangan pasangan, menerima stigma, beban membesarkan anak, dan beban ekonomi.

Maghfur dan Muniroh (2013) mendukung kategori ini. Mereka menyebut istri dan keluarga adalah korban tidak langsung dari tindakan terorisme suami. Bentuk-bentuk penderitaan mereka di antaranya menjadi janda karena suaminya meninggal dalam aksi teror, anak menjadi yatim piatu, dan orangtua kehilangan anak.

Selama suami di dalam penjara, istri mengambil alih semua peran rumah tangga. Mereka bahkan berperan dalam meringankan beban psikologis dan ekonomi suami. Studi Sarwono (2016) menemukan semua istri menjadi teman curhat utama bagi suami. Selain itu mereka men-support kebutuhan ekonomi 
suami dengan cara menyiapkan bahan mentah dan olahan untuk dijual suami di dalam Lapas, berjualan di rumah dan memberi uang kepada suami dari hasil usaha tersebut.

Dalam hal kontra terorisme, istri punya peran penting. Studi Sarwono (2016) menemukan istri-istri yang berani mengingatkan agar suami tidak mengulangi lagi perbuatannya. Saat keluar dari tahanan nanti suami harus fokus pada pekerjaan dan keluarga saja, tidak kembali berkomunikasi dengan temantemannya di kelompok radikal.

\section{METODE}

\section{Partisipan}

Subjek penelitian ini adalah 4 orang istri narapidana teror (napiter) yang berasal dari Jakarta, Semarang, dan Cilacap. Satu orang adalah istri napi kasus konflik Poso dengan hukuman 4 tahun penjara (disebut subjek A). Pada bulan Mei 2016 lalu suaminya bebas dari penjara.

Dua orang adalah istri (istri pertama dan istri kedua, disebut subjek B dan C) napi kasus bom di Solo yang saat ini ditahan di Lembaga Pemasyarakatan (Lapas) Kedungpane Semarang dengan vonis 6 tahun.

Satu orang adalah istri napiter kasus konflik Ambon yang ditahan di Lapas Batu, Nusakambangan (disebut subjek D). Nama dan inisial subjek tidak disebutkan karena alasan etika penelitian dan keselamatan subjek.

\section{Desain}

Penelitian ini adalah penelitian kualitatif dengan metode pengambilan data wawancara. Wawancara kepada 3 subjek dilakukan dengan izin dari suami dan subjek sendiri, sementara kepada 1 subjek dilakukan dengan metode investigasi (tanpa izin dari subjek).

Pertanyaan-pertanyaan wawancara antara lain: apa tanggapan subjek mengenai penangkapan suami, bagaimana sikap terhadap pihak-pihak yang telah menangkap suami, bagaimana kalau suami bergabung dengan kelompok radikal lagi, apa harapannya terhadap suami, apa rencana masa depan subjek.

\section{Prosedur}

Sebelum melakukan wawancara, peneliti mengajukan izin kepada suami 3 subjek untuk melakukan kunjungan kepada istri. Setelah mendapat izin suami peneliti melakukan wawancara di 
tempat yang diinginkan subjek. Peneliti mengikuti pilihan subjek karena pada umumnya mereka mempunyai norma-norma sendiri, seperti menghindari restoran terkait Amerika dan Barat.

Wawancara dengan subjek A dilakukan di rumah subjek A. Dengan subjek B dan C dilakukan di Lapas Kedungpane setelah mereka mengunjungi suami. Dengan subjek D dilakukan di Lapas BatuNusakambangan saat peneliti melakukan kunjungan ke sana.

\section{Teknik Analisis}

Jenis teknik analisis yang digunakan adalah qualitative thematic analysis yang dilakukan melalui tiga langkah. Pertama, data hasil wawancara yang terkumpul (dari rekaman) ditranskrip/ dipaparkan secara apa adanya. Kedua, koding data, yaitu mencari pernyataan-pernyataan yang relevan dengan fokus penelitian. Ketiga, analisis dan penarikan kesimpulan. Namun untuk subjek D hanya memanfaatkan catatan lapangan dan kutipan-kutipan wawancara karena tidak memungkinkan untuk melakukan perekaman.

\section{ANALISIS DAN HASIL}

Berdasarkan hasil analisis, 2 subjek memandang tindakan teror yang dilakukan suami adalah benar (pro) dan 2 subjek memandang salah (kontra). Pandangan pro diberikan oleh subjek A dan D, pandangan kontra diberikan oleh subjek B dan C. Subjek A menganggap tindakan suaminya hanyalah dakwah, bukan bagian terorisme seperti yang didakwakan pengadilan.

Suami A diidentifikasi sebagai anak buah Santoso, pimpinan kelompok radikal yang sampai saat ini beroperasi di Poso. Ia ditangkap pada Desember 2012 dan divonis 4 tahun dengan dakwaan mengikuti tadrib (pelatihan teror) dan menyembunyikan buronan kasus terorisme (Redaksi, 2012). A pindah ke Jakarta agar dekat dengan suami yang ditahan di Lapas Cipinang. Sebanyak 2 kali dalam seminggu A membesuk suami.

Subjek A memiliki tingkat kepatuhan yang tinggi terhadap suami. Dalam wawancara, A sering mengungkapkan kalimat "terserah abinya saja" dan "saya kan ikut abinya" ketika ditanya pendapatnya. 
Soal pandangan terhadap ISIS misalnya, A mengatakan tidak seperti ISIS karena suami mengatakan demikian. Berikut adalah pernyataan A:

"Kalau abinya nggak suka. Saya kan ikut abinya. Iya kan, macam kita begini kalau kayak ISIS begitu kita nggak mau. Soalnya kan kita nggak mau mengkafirkan. Kalau ISIS kan gitu. Kalau kita kan di luar ISIS. Nggak mau. Nggak mau ikutan ikut campur ISIS. Karena kita bukan ISIS." (Subjek A, wawancara 4 Januari 2016).

Demikian pula saat ditanya mengenai rencana masa depan, A banyak menggantungkan kepada suami.

"Biasanya sama abinya ya ngobrol ke depannya begini, nah abinya itu bilang 'besok ya dipikir besok mi. Hidup gak ada yang tau sampai kapan' gitu. Jadi saya gak mau lagi bahas. Kita ini gak usah berangan-angan besok itu apa ya? kalau abinya kayak begitu 'Allah semua kan yang menentukan mi, kita jangan berharap apa-apa'. Besok ya besok gitu kalau abinya. Nanti kalau suami sudah keluar baru dirancang. Insyaallah ada aja nanti kalau suami sudah keluar. Sekarang dipikir enjoy aja, abinya bilang nggak usah dipikir macam-macam. santai saja. (Subjek A, wawancara 7 April 2016).

Kepatuhan yang tinggi membuat subjek A lebih sering sependapat dengan suami. Apabila suami mengatakan tindakannya tidak salah, A berpendapat sama. Berdasarkan keterangan-keterangan A, suaminya sering protes terhadap Lapas, polisi, dan Densus. Di antaranya, A tidak ingin ada tulisan "blok teroris" di depan selnya dan mengatakan pemerintah sering memberi harapan palsu terkait pembebasannya. Sikap itu sangat berpengaruh terhadap sikap A.

Perkenalan subjek A dengan Islam radikal terjadi pada saat pecahnya konflik Poso sekitar tahun 2000-an. Pada saat itu banyak Ustadz Laskar Jihad dari Jawa yang datang ke Poso untuk membantu Muslim melawan Nasrani. Mereka melakukan pengajian-pengajian kepada Muslim Poso.

Subjek A dan suami adalah dua di antara masyarakat Muslim Poso yang bergabung dalam pengajian ustadz-ustadz Laskar Jihad. Dari pengajian-pengajian itu A banyak menyerap faham Islam radikal. Keputusan mengenakan gamis dan cadar pun diambil setelah banyak mendengar ceramah dari para Ustadz.

Suami subjek A turut bersyiar bersama para Ustadz dengan cara memberikan ta'lim (pengajian) ke desa-desa. Aktivitas bertani kakao mulai ditinggalkan karena kegiatan tersebut. A pun sering ikut mendampingi suami berdakwah. 
Bagi subjek A apa yang dilakukan suami adalah murni dakwah. Tidak pernah suami melakukan hal lain kecuali berdakwah. Tuntutan yang didakwakan adalah rekayasa Densus. Keyakinan itu disampaikan A sebagai berikut:

"Iya mbak santai aja sudah. Tapi ya pas waktu pertama ditahan itu jelas kaget, kasus apa abi ini abinya kan gak tau ada apa ini kok sampai ditangkap. Kan abinya selama ini gak pernah ikut ke mana-mana, apalagi sampai mendanai orang uang aja susah. Kan abi itu tuduhannya mendanai itu mbak tapi itu kan cuma rekayasa dari Densus aja, abinya itu gak punya uang gak pernah mendanai. Cuma ikut dakwah gitu aja gak pernah mendanai gitu itu gak pernah.” (Subjek A, wawancara 7 April 2016).

Keputusan suami untuk berdakwah dinilai sangat terpuji karena tujuannya membela Islam yang sedang diperangi oleh Kristen. Subjek A punya pandangan negatif terhadap Kristen. Ia sangat yakin bahwa Muslim sedang berusaha ditumpas Kristen sehingga harus dibela. Dalam wawancara A menyatakan:

"Kalau itu kan orang kafir duluan yang bantai kita. Jadi mereka nggak suka dengan orang Islam gitu. Sampai orang Islam itu yang hamil dibelah, dikasih keluar bayinya. Ya mereka nggak suka dengan agama Islam.”

Kata yang digunakan A untuk menunjuk Kristen adalah "kafir", bukan "Kristen" atau "non Muslim”. Sebutan itu menunjukkan tingkat persepsi negatif terhadap umat Kristen. A juga memandang Kristen sebagai pelaku penyerangan dan Muslim adalah korban. Jika Kristen tidak menyerang lebih dulu, konflik di Poso tidak akan terjadi. Sementara yang dilakukan Muslim adalah membela diri dan hal itu sudah sepatutnya dilakukan.

Bagaimana subjek A memandang Kristen menjadi faktor penting bagi sikap A terhadap aksi teror. Secara jelas subjek A memandang Kristen sebagai musuh. Kristen dianggap tidak suka pada Islam dan bertujuan menghancurkan Islam. Dalam pernyataan-pernyataannya, A tidak pernah memandang Islam juga sebagai pelaku dalam konflik Poso. Meskipun ada orang Islam yang melakukan kekerasan terhadap Kristen, hal itu tidak masuk dalam perhatiannya.

Subjek A tidak keberatan suami berdakwah seperti dulu karena menurutnya dakwah adalah ibadah. Keyakinan bahwa suami tidak bersalah didukung pandangan dizolimi (Islam sebagai korban) membuat A mendukung suami untuk berdakwah kembali. Sikap tersebut terdapat pada petikan wawancara berikut:

T: Umi kan berharap abinya keluar, program ke depan umi setelah abi keluar itu apa? Program umi setelah abinya keluar gitu apa?

J: Enggak sih biasa aja, dakwah aja. Fokus aja ke ini apa ya maksudnya, enggak kok biasa aja. Fokuskan aja beribadah. 
Faktor berikutnya adalah kurangnya informasi yang diterima subjek A mengenai kegiatan suami. Yang A ketahui suami hanya mengisi ta'lim dari desa ke desa. Meskipun sering mendampingi suami saat memberi ta'lim, sebagian besar waktu A dihabiskan di rumah sehingga tidak tahu kegiatan suami di luar ta'lim. Hal itu dapat ditemukan pada pernyataan berikut:

"Ya kita sebagai perempuan ya ada di rumah, nggak pernah tau apa-apa, cuma ikut-ikut ta'lim - ta'lim aja. di sana kan bapaknya nggak pernah pergi-pergi kemana-mana, cuma ta'lim-ta'lim juga, dia itu juga na'limin-na'limin temen-temen disana tuh abinya jadi ustadznya." (Subjek A, wawancara 4 Januari 2016).

Subjek D adalah subjek kedua yang bersikap pro terhadap tindakan suami. Secara tegas ia menyampaikan dukungannya untuk suami. Suami D terlibat dalam konflik Islam-Kristen di Ambon dan saat ini ditahan di Lapas Batu, Nusakambangan. Menurut subjek D apa yang dilakukan suami adalah tindakan mulia karena bertujuan untuk membela Islam dari kelompok yang memusuhi.

Subjek D berpandangan sangat radikal. Ia bertemu dengan suami saat suami sudah berstatus buronan. Namun status itu tidak jadi masalah untuk menikahi suami. Seminggu setelah taaruf (perkenalan), D dan suami menikah. Selang beberapa saat suami D tertangkap dan ditahan di Ambon. D tinggal di Ambon selama 6 tahun. Dua anaknya lahir saat suami ditahan di Ambon dan 1 anak saat suami ditahan di Nusakambangan.

Kebutuhan sehari-hari dicukupi dengan cara membelanjakan pesanan dari napi-napi di dalam Lapas. Suami yang menerima pesanan dan D membelanjakannya. Barang-barang yang dipesan biasanya sabun, sandal, pakaian, dan makanan. Penghasilan dari usaha itu tidak selalu cukup untuk kebutuhan pokok. D mengaku kadang tidak dapat makan karena tidak punya uang, sementara anak yang diasuhnya ada 3 orang. Apabila tidak ada uang untuk makan, D biasanya berpuasa.

Sejak sebelum menikah D sudah menyadari akan menghadapi kondisi susah. Namun hal itu justru jadi tantangan bagi D. D mengaku sejak gadis tidak suka laki-laki yang hanya di rumah saja. Aktivitas suami sebagai seorang mujahid membuatnya sangat tertarik, meskipun tahu akan ditangkap dan hidup susah.

D memandang kehidupan susah adalah bagian dari perjuangan membela Islam. Ia sangat yakin tindakan suami dalam konflik Islam-Kristen di Ambon adalah jihad. Meskipun akhirnya di penjara, bukan berarti suaminya bersalah. Dipenjara karena membela Islam juga bagian dari jihad. Ia mengatakan insya Allah suaminya tetap mendapat pahala dari Allah meskipun berada di dalam penjara. D yang bersabar mendampingi dan menunggu suami selama masa tahanan insya Allah juga akan mendapat pahala. Keyakinan itu sangat kuat dan menjadi pedoman hidup D. 
Kondisi susah selama suami di dalam penjara tidak memberikan efek jera kepada D. Ia juga tidak menyiratkan rasa menyesal karena semua yang dilalui adalah perjuangan mulia. D tidak masalah apabila suami kembali ke aktivitas terorisme setelah keluar dari tahanan nanti. Jika ditangkap lagi pun tidak masalah karena terdapat nilai perjuangan di dalamnya. Sikap tersebut dapat disimak pada kutipan wawancara di bawah ini:

T: Kalau nanti keluar terus abinya kembali seperti dulu bagaimana, Umi?

J: Ya nggak apa-apa.

T: Nanti ditangkap lagi bagaimana dong?

J: Ya nggak apa-apa, Mbak. Namanya hidup ya begitu. Malah ada perjuangannya. Kalau kaya'orang-orang yang di luar sana, ya bisa. Semua orang hidup begitu ya bisa. Tapi kan nggak ada perjuangannya. (Subjek D, wawancara 25 April 2016).

D memaknai aktivitas terorisme suami adalah bagian dari perjuangan.

Berbeda dengan A dan D, subjek B dan C bersikap kontra terhadap tindakan teror suami. Menurut $\mathrm{B}$ dan $\mathrm{C}$, suami ditangkap karena bersalah dan tindakan teror yang telah dilakukan suami tidak dapat dibenarkan. Jika tidak bersalah tidak mungkin polisi menangkap. B tidak menyalahkan pihak lain karena menurutnya semua disebabkan kesalahan suami. Polisi dan Densus 88 hanya menjalankan tugas, tidak dapat disalahkan karena telah menangkap suami.

Sikap itu bertolak belakang dengan subjek A. Hingga saat wawancara A masih sangat kesal terhadap cara Densus 88 saat menangkap suaminya. Ia mendengar suami ditendang dari sepeda motornya saat proses penangkapan. Subjek A tidak dapat memaklumi tindakan itu sebagai bagian tugas Densus 88 .

Kutipan wawancara berikut menunjukkan sikap B terhadap tindakan teror suami.

Yang salah ya suamiku. Kalo suamiku gak berbuat kan gak digituin (dipenjara) ya kan? Dendamnya ke siapa dulu? Ke suami karepmu opo tho iki? Gitu tok. Tapi kalo yang lain nggak lah, itu kan udah tugasnya.[Dendamnya ke siapa dulu? Ke suami maumu apa sih ini? Begitu aja. Tapi kalau ke yang lain tidaklah, itu kan sudah tugasnya.] Intinya saya tuh kalo gak pernah berbuat kan gak pernah ada seperti itu. Kalo dia gak aneh-aneh gitu loh, kalo gak aneh-aneh kan gak mungkin kesana. Gak mungkin sampe kesitu (penjara). Cuma nyalahin suami sendiri gak ke siapa-siapa. Ya intinya kan suami sendiri Mba. Ke siapa? Ke suami sendiri. Polisi kan hanya menjalankan tugas ya. Kalo gak ada orang salah ga mungkin. Hayo kalo gak ada orang gak berbuat salah gak akan mungkin. (Subjek B, wawancara 14 April 2016) 
Sikap kontra B terhadap suami dapat disebabkan oleh independensi yang tinggi. Hal itu dapat diketahui dari pernyataan-pernyataan yang menunjukkan kemandirian. Misalnya saat ditanya mengenai rencana masa depan, B menyatakan sebagai berikut:

"Oh kalo dari saya sendiri pengennya usaha mandiri gak tergantung suami. Intinya gak tergantung suami. Kalo suami ada Alhamdulillah, kalo gak ada ya harus usaha bisa cari sendiri." (Subjek B, wawancara 14 April 2016).

Markus dan Kitayama (1991) membagi penggambaran diri manusia ke dalam kategori independen (independent self-construal) dan interdependen (interdependent self-construal). Orang independen menggambarkan diri mereka sebagai kesatuan yang terpisah dari konteks sosial. Sementara orang interdependen sebaliknya, yaitu menggambarkan diri tidak terpisah dari konteks sosial.

Konteks sosial dalam konsep teori self-construal adalah orang lain di dalam hidup kita, dapat berupa ibu, bapak, saudara, teman, teman kerja, dan pasangan. Orang yang merasa tidak terpisah dengan orang lain memiliki tingkat kelekatan yang kuat. Implikasinya dapat pada pengambilan keputusan, kemampuan mengekspresikan diri, kemauan berkata terus terang, dan sikap berani.

Faktor kedua adalah hubungan egaliter yang terbangun antara B dengan suami. B dan suami melalui proses pacaran cukup lama sebelum memutuskan menikah. Mereka membangun rumah tangga dari nol bersama-sama. Kontribusi yang diberikan B dalam membangun rumah dan mendampingi suami sangat besar. Posisi tersebut memungkinkan ia tidak takut menyalahkan tindakan suami.

Faktor ketiga adalah latar belakang pendidikan. B tidak pernah mengenyam pendidikan pesantren. Dulu penampilannya seperti muslimah Indonesia pada umumnya (bukan gamis dan hijab panjang). Keputusan mengenakan gamis dan cadar baru saja diambil atas permintaan suami. B juga pernah bekerja sebagai asisten anggota DPR di Jakarta. Semenjak suami ditahan, sebetulnya B ingin bekerja tetapi tidak dapat izin dari suami.

Faktor keempat adalah trauma dan stigma akibat tindakan suami. B sangat terpukul atas keadaan yang dihadapi. Pada saat suaminya ditangkap, B sedang dalam kondisi menyusui anaknya yang baru berusia 6 bulan. Ia harus bolak-balik Yogyakarta sampai Depok (Mako Brimob) untuk mendampingi suami. B juga pernah mendatangi dan memarahi istri teman yang mengajak suami terlibat dalam aksi teror. 
Penyesalan B diungkapkan dalam kutipan berikut:

"Penyesalannya saya tuh gini Rutan Mako Kelapa Dua itu masuknya ya Allah ya Rabbi. Waktu dia masih 6 bulan. Kalo disini (Lapas Kedungpane) mah masih mending kalo disana ya Allah kapok udah deh jangan pernah diulang lagi. Itu penyesalan saya 1 tahun disana Mbak." (Subjek B, wawancara tanggal 14 April 2016).

Sampai saat ini B merahasiakan status suami dari orangtua, keluarga besar, dan tetangga-tetangga. Ia mengatakan suami sedang bekerja di luar negeri. Tidak ingin mendapat stigma negatif adalah alasannya mengambil pilihan tersebut. Menjaga kondisi psikologis anak juga menjadi pertimbangan utama untuk merahasiakan status suami. Hal itu semakin jelas oleh keinginan pindah kota. Dalam wawancara tanggal 14 April 2016, B menyampaikan ingin pindah ke Batam untuk memulai hidup baru. Ia ingin menjauhkan diri dan anaknya dari stigma negatif dan jaringan Islam radikal suami.

Status dipoligami menjadi faktor lain yang membuat B ingin menjauh dari kehidupannya sekarang. Ia mengatakan tidak masalah jauh dari orangtua dan keluarga demi kehidupan baru yang diinginkan. Menurut B, hubungan dengan orangtua dan keluarga dapat tetap dijaga karena sudah ada telepon dan fasilitas komunikasi lainnya.

Subjek C juga bersikap kontra terhadap tindakan suami. Salah satunya terdapat pada kutipan wawancara berikut:

“Yang salah yang berbuat (suami)” (Subjek C, wawancara 14 April 2016).

Menurut analisis peneliti, sikap kontra $\mathrm{C}$ didorong keinginan hidup bahagia bersama suami. Kondisi $\mathrm{C}$ yang pernah gagal berumah tangga dan faktor usia membuatnya tidak ingin terpisah lagi dengan suami. Dalam wawancara C menyampaikan:

"Ya kalo kita mah yang penting pengen cepet keluar udah gitu aja. Udah disitu udah kunci jawabannya lah. Pengen Abi bebas pengen kita usaha udah. Ya ngerti lah berarti kita disitu pengennya apa. Dengan keadaan seperti ini kan tau kan. Nah kalo kemaren Abi masih ada rasa penyesalan gitu." (Subjek C, wawancara 14 April 2016).

Namun demikian, sikap C tidak setegas B. Ungkapan kontra tidak disampaikan sesering B. Hal itu dapat disebabkan oleh pengalaman kegagalan rumah tangga $\mathrm{C}$ sebelumnya sehingga bersikap lebih hati-hati dengan suami sekarang. C menikah dengan suami dalam status janda. Usianya pun lebih tua dari suami. Suami adalah sosok yang telah mengembalikan kebahagiaan $\mathrm{C}$ dan telah memberinya anak. Kondisi itu memungkinkan C mempunyai konformitas lebih tinggi dibanding B. Sikap C sejalan dengan prinsip 
teori aktor rasional yang menyatakan seseorang akan menurut ketika melihat ada manfaat dari tindakan menurutnya dan tidak melihat adanya konsekuensi negatif (Monroe, dalam Shiraev \& Levy, 2012). Keberadaan anak yang masih bayi adalah faktor pendukung yang membuat $\mathrm{C}$ menghindari konsekuensi negatif dari sikapnya. C mengambil jalan tengah, yaitu "bersikap kontra" terhadap tindakan teror suami, namun dengan sikap lunak untuk menghindari konsekuensi negatif. Namun demikian, yang menjadi poin penting dalam penelitian ini adalah "sikap kontra" $\mathrm{C}$, terlepas dari bagaimana sikap itu disampaikan.

\section{DISKUSI}

Penelitian ini menemukan bahwa sikap istri tidak selalu sama dengan suami. Dua dari empat partisipan dalam penelitian ini kontra terhadap tindakan teror suami. Sikap tersebut dapat dipengaruhi oleh tingkat kepatuhan terhadap suami, pandangan negatif terhadap Kristen, ketidaktahuan pada aktivitas terorisme suami, pemaknaan perjuangan Islam (jihad) dengan angkat senjata, pendidikan Islam radikal, karakter independen/mandiri, hubungan egaliter dengan suami, latar belakang pendidikan umum, pengalaman trauma dan stigma, dan keinginan hidup bahagia bersama suami.

Hasil penelitian menemukan faktor karakter (independensi) dan faktor eksternal berkontribusi terhadap sikap partisipan. Namun demikian, faktor eksternal berpengaruh lebih besar. Temuan ini sejalan dengan Kruglanski dan Fishman (2006), Sarwono (2012), McCauley (2002), dan Kruglanski dan Golec (2008).

Hubungan pandangan negatif terhadap non-Muslim dengan sikap terhadap terorisme mendukung hasil penelitian Putra dan Rufaedah (2010) dan Putra dan Sukabdi (2013). Dalam penelitian itu dikatakan bahwa terorisme didorong oleh rasa dizolimi. Misalnya dalam konflik Poso, Ambon, dan Palestina, Muslim diserang oleh Kristen. Dalam kondisi seperti itu Muslim harus membantu meskipun dengan cara angkat senjata.

Pandangan di atas juga sejalan dengan temuan Maghfur dan Muniroh (2013). Dalam penelitiannya, partisipan menyatakan Muslim di Palestina, Afghanistan, Ambon, dan tempat-tempat lain sedang berusaha dihancurkan oleh kafir Yahudi yang disokong Amerika. Amerika adalah biang terorisme. Orang yang teriak terorislah yang seharusnya disebut teroris, bukan orang yang sedang memperjuangkan Islam.

Partisipan pro penelitian ini memang tidak melakukan aksi teror seperti partisipan penelitian Putra dan Rufaedah (2010) dan Putra dan Sukabdi (2013), namun sikapnya jelas mendukung. Hal ini memunculkan pertanyaan menarik: "jika istri menganggap non-Muslim sebagai musuh dan diizinkan ikut berjihad, apakah mereka akan melakukan tindakan teror seperti para suami?” 
Jawabannya: "mungkin iya". Dalam sejarah terorisme dunia pada faktanya juga diwarnai oleh perempuan, di antaranya adalah Nadia Lioce, Margherita Cagol, Adriana Faranda, Barbara Balzerani, Susanna Ronconi, dan Francesca Mambro. Mereka adalah para pendiri dan pelaku organisasi terorisme politik di Italia antara tahun 70-80an. Sebagian dari mereka ada yang terbunuh saat melakukan aksi (Glynn, 2013).

Perbedaan istri teroris dengan perempuan-perempuan teroris hanya pada kewajiban sebagai istri. Dalam ajaran kelompok radikal, kewajiban istri adalah mengurus rumah, melayani suami, dan mendidik anak. Wilayah mereka adalah rumah. Jika istri teroris diizinkan turun ke medan perang, mereka dapat sama berbahayanya dengan laki-laki. Banyak istri teroris yang pemikirannya telah memenuhi syarat untuk menjadi teroris. Seperti salah satu partisipan dalam penelitian ini yang secara terang-terangan mendukung aksi teror suami. Ia tidak takut hidup susah selama suami di dalam penjara karena baginya angkat senjata adalah jihad.

\section{SIMPULAN DAN SARAN}

\section{Simpulan}

Penelitian ini menemukan pemaknaan-pemaknaan penting yang melandasi sikap pro dan kontra terhadap tindakan teror suami. Bagi partisipan pro, tindakan teror suami diartikan sebagai dakwah dan perjuangan Islam (jihad), sedangkan bagi partisipan kontra diartikan kesalahan suami. Bagi partisipan pro, suami tidak bersalah karena sedang melakukan tugas yang seharusnya memang dikerjakan, yaitu membela Islam

Sikap pro dipengaruhi kepatuhan terhadap suami, pandangan negatif terhadap Kristen, ketidaktahuan pada aktivitas terorisme suami, pemaknaan perjuangan Islam (jihad), dan pendidikan Islam radikal. Sikap kontra dipengaruhi karakter independen atau mandiri, hubungan egaliter dengan suami, latar belakang pendidikan umum, pengalaman trauma dan stigma, dan keinginan hidup bahagia bersama suami.

\section{Saran}

Hasil penelitian ini dapat digunakan dalam upaya kontra terorisme melalui istri dengan cara menurunkan ketergantungan istri, dapat berupa dalam hal ekonomi, pemikiran, cita-cita, atau konsep hidup, menawarkan konsep hubungan setara dengan suami, pendidikan anti radikal melalui tafsir ulang teks-teks agama, dan memberi gambaran konsekuensi dari tindakan terorisme suami terhadap diri, anak-anak, orangtua, dan keluarga besar. 


\section{UCAPAN TERIMA KASIH}

Ucapan terima kasih saya sampaikan kepada Dr. Phil. Idhamsyah Eka Putra, M.Si., yang selalu memberi motivasi untuk menulis dan kepada Profesor Sarlito W. Sarwono yang selalu menginspirasi. Terima kasih pula kepada semua tim PRIK UI yang selalu bersemangat dalam bekerja dan berkarya.

\section{REFERENSI}

Bandura, A. (1990). Mechanisms of moral disengagement. Dalam W. Reich (Ed.), Origins of terrorism: Psychologies, ideologies, theologies, states of mind (p. 161-191). Cambridge, UK: Cambridge University Press.

Glynn, R. (2013). Women, terrorism, and trauma in Italian culture. New York, NY: Palgrave Macmillan.

Kruglanski, A. W., \& Fishman, S. (2006). The psychology of terrorism: "Syndrome" versus "tool" perspective. Terrorism and Political Violence, 18, 193-215.

Kruglanski, A. W., \& Golec, A. (2008) Individual motivation, the group process and organizational strategies in suicied terrorism. Dalam E. M. Meyersson-Milgrom (Ed.), Suicide Missions and the Market for Martyrs, A Multidisciplinary Approach (pp. 1-21). Princeton, NJ: Princeton University Press.

Lizardo, O. (2008). Defining and theorizing terrorism: A global actor-centered approach. Journal of World-Systems Research, 14(2), 91-118.

Maghfur, \& Muniroh, S. T. (2013). Perempuan di balik teroris (Religiusitas, penyesuaian diri dan pola relasi suami istri tersangka teroris di Kota Pekalongan). Jurnal Analisa, 20(02), 181-195.

Markus, H. R., \& Kitayama, S. (1991). Culture and the self: Implications for cognition, emotion, and motivation. Psychological Review, 98, 224-253.

McCauley, C. R. (2002). The psychology of terrorism (essay excerpt). Terrorism: Essential Primary Sources, 448-451.

Merari, A. (2007). Terrorism as a strategy of insurgency. Dalam G. Chaliand and A. Blin (Eds.), The history of terrorism: From antiquity to Al Qaeda (pp. 12-54). London, UK: University of California Press Ltd.

Milla, M. N., \& Faturochman. (2009). Pembentukan identitas mujahid global pada terpidana kasus 
terorisme di Indonesia. Jurnal Psikologi Indonesia, 6(2), 82-96.

Moghaddam, F. M. (2005). The staircase to terrorism: A psychological exploration. American Psychological Association, 60, 161-169.

Nursalim, M. (2014). Deradikalisasi terorisme: Studi atas epistemology, model interpretasi, dan manipulasi pelaku teror. Kalam: Jurnal Studi Agama dan Pemikiran Islam, 8(2), 329-346.

Post, J. M. (2005). The psychological and behavioral bases of terrorism: Individual, group and collective contributions. International Affair Review, 14(2), 195-203.

Putra, I. E., \& Rufaedah, A. (2010). Mencari akar munculnya terorisme Islam di Indonesia. Jurnal Ilmiah Psikologi, 4, 86-95.

Putra, I. E., \& Sukabdi, Z. A. (2013). Basic concepts and reasons behind the emergence of religious terror activities in Indonesia: An inside view. Asian Journal of Social Psychology, 16, 83-91.

Redaksi. (2012). Dua Tangkapan Densus di Poso Diduga Anak Buah Santoso. Beritasatu.com. Ditemu kembali dari http://www.beritasatu.com/nusantara/89987-dua-tangkapan-densus-di-poso-didugaanak-buah-santoso.html

Ross, J. I. (1996). A model of the psychological causes of oppositional political terrorism. Peace and Conflict: Journal of Peace Psychology, 2(2), 129-141.

Sarwono, S. W. (2012). Terorisme di Indonesia dalam tinjauan psikologi. Jakarta, Indonesia: Alvabet.

Sarwono, S. W. (2016). In-Prison Re-Education Programme: A Strategy in Countering ISIS Ideology for Terror-Convicts and Families. Laporan penelitian tidak diterbitkan. Jakarta, Indonesia: Pusat Riset Ilmu Kepolisian Program Pascasarjana Universitas Indonesia.

Shiraev, E. B., \& Levy, D. A. (2012). Psikologi lintas kultural: Pemikiran kritis dan terapan modern (4th ed.). Jakarta, Indonesia: Kencana Prenada Media Group.

Victoroff, J. (2005). The mind of the terrorist: A review and critique of psychology approaches. The journal of conflict resolution, 49(1), 3-42. 